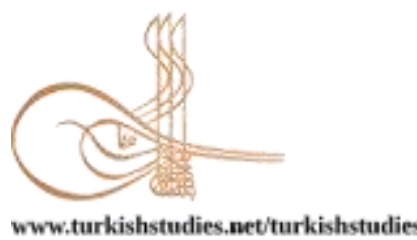

Turkish Studies

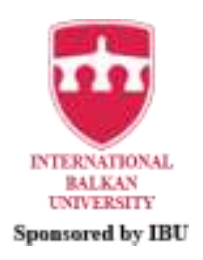

\title{
Sosyal Hizmet Bölümü Stajyer Öğrencilerinin İş Bulma Kaygısını Azaltmaya Yönelik Grup Çalışması
}

Group Work Towards Reducing Finding A Job Anxlety of Department of Social Work Interns

\author{
Fatih Cebeci* - Taner Artan ${ }^{* *}$ - Merve Karaman***
}

\begin{abstract}
Objective: The purpose of this work is to test the efficiency of the group work designed to increase motivation of interns for finding job by sharing knowledge and skills towards reducing finding job anxiety and hopelessness of the department of social services interns. Method: Workgroup is formed of 7 interns from senior students of the department of social services in various universities that does an internship in the child welfare field. The efficiency of the session that consisted of 7 meetings is measured by applying Beck Hopelessness Scale and The State-Trait Anxiety Inventory of all participants before the first meeting and after the last meeting; thus applying for a pretest-posttest work. Research data is evaluated in SPSS Statistics 22.0 software. Wilcoxon Signed Rank Test applied and collected feedback from participants through analyzing the data. Results: When the pretest and posttest scores of the Beck Hopelessness Scale and State-Trait Anxiety Scale which conducted before the first session and after the seventh session of the group work that is designed to reduce the job anxiety and hopelessness of the intern students studying in the social work department are analysed, no meaningful difference found. However; Considering the pretest and posttest scores of the group members, there was a significant decrease in anxiety and hopelessness levels. Conclusion: Even though there is not any remarkable difference in the level of finding job anxiety and hopelessness of the department of social services interns before and after the work, there is a significant decrease in anxiety and hopelessness scores of interns. This group work with social work department internship students will contribute to the field in terms of both being a social work practice with groups and being a vocational counselling practice for university students.
\end{abstract}

Structured Abstract: Introduction: Despair is a concept which expresses that the individual has negative expectations from the future to achieve his future goals. If an individual has a sense of despair, he has prejudice that he will fail to achieve future goals. Anxiety is one of the other basic emotions that exists in human beings, and it is assumed that this anxiety originates from an uncertain fear. This feeling, just like the feeling of fear,

\footnotetext{
* Sosyal Hizmet Uzmanı, Dr. Öğrencisi, İstanbul Üniversitesi- Cerrahpaşa, Sağlık Bilimleri Fakültesi, Sosyal Hizmet Social Worker, PhD Student, Istanbul University, Faculty of Health Sciences, Department of Social Work ORCID 0000-0003-3866-5967

fatihalpcebeci@gmail.com

** Doç. Dr., İstanbul Üniversitesi- Cerrahpaşa, Sağlık Bilimleri Fakültesi, Sosyal Hizmet Bölümü Assoc. Prof. Dr., Istanbul University, Faculty of Health Sciences, Department of Social Work ORCID 0000-0002-8716-2090

taner.artan@istanbul.edu.tr

*** Sosyal Hizmet Uzman1, Dr. Öğrencisi, İstanbul Üniversitesi- Cerrahpaşa, Sağlık Bilimleri Fakültesi, Sosyal Hizmet Social Worker, PhD Student, Istanbul University, Faculty of Health Sciences, Department of Social Work ORCID 0000-0002-3210-3325 merve.389206@gmail.com

Cite as/ Atıf: Cebeci F., Artan, T., Karaman, M. (2020). Sosyal hizmet bölümü stajyer öğrencilerinin iş bulma kaygısını azaltmaya yönelik grup çalışması. Turkish Studies, 15(3), 1721-1738. https://dx.doi.org/10.29228/TurkishStudies.43350

Received/Geliş: 04 May/Mayıs 2020

Accepted/Kabul: 20 June/Haziran 2020

Copyright $\odot$ MDE, Turkey
} 
is seen as a defence mechanism in human, and it is defined as a feeling used by man to protect himself from danger. Spielberger et al. (1983) explained anxiety stateful and continuously. While state anxiety is expressed as a result of the instant emotional state that the individual is in, continuous anxiety is defined as the tendency to react with anxiety in stressful moments (Spielberger, Jacobs, Russell, \& Crane, 1983). While the number of people receiving university education in our country is increasing rapidly, the employment rates of students who graduate from the university decrease. One of the most critical factors affecting the hopelessness and anxiety levels of especially senior students studying at universities is the availability of employment after graduation (Dursun \& Aytaç, 2009).

Objective: In this study, it was aimed to strengthen the mental status and motivation of finding a job by increasing the knowledge of the social work department intern students about the social work profession and job opportunities and bringing skills to cope with job anxiety.

Methods: The pre-test-post-test experimental design without a control group was used in this research in order to test the effectiveness of the group work designed to increase the motivation of the students by sharing knowledge and skills to reduce the job anxiety and hopelessness of the intern students. The study group of this research consists of 7 students who volunteered and participated in the study at the final year of the social work department of various universities who are doing internships in a public institution related to child welfare in the spring term of 2018-2019 academic year. The group work is designed to consist of seven sessions. In this study, the fact that the group members are from different universities is also crucial for the accomplishment of the group work. Group work consists of six questions which include age and gender of group members, whether they want to choose the social work department or not, the hope of finding a job after graduation, the period of hoping that they can find a job after graduation and whether they receive vocational career guidance for their departments or not. Personal Information Form was applied as a pre-group evaluation to the group members at the beginning of the group work and as a post-group evaluation form to the group members at the end of the group process. The data obtained after the pretest and posttest applications with "Beck Hopelessness Scale" and "State-Trait Anxiety Scale" were analysed in SPSS Statistics 22.0 statistical program in the computer environment. Wilcoxon Signed Rank Test were used in the analysis of the data.

Result and Discussion: The group work carried out to increase the motivation of students for employment by sharing information and skills to reduce the anxiety and despair of intern students in the social work department was realised as seven sessions as planned. The group process generally continued as follows:

- Warm-up games and drama activities were held for each session, and participants were motivated to participate.

- Each session started with a warm-up activity, then the information was shared on the topic planned for that session, and at the end of the session, evaluations were received from each group member about how the session passed, and participants were given homework assignments. Throughout the group, sessions were not excluded from the general flow, and the meetings took place as planned.

- $\quad$ Each session lasted on average as 75 minutes as planned.

When the pretest and posttest scores of the Beck Hopelessness Scale and State-Trait Anxiety Scale which conducted before the first session and after the seventh session of the group work that is designed to reduce the job anxiety and hopelessness of the intern students studying in the social work department are analysed, no meaningful difference found. However; Considering the pretest and posttest scores of the group members, there was a significant decrease in anxiety and hopelessness levels. In addition, the opinions received from the group members at the end of the group work support this finding. According to another outcome of the research, $28.58 \%$ of the participants said "Yes" to the hope that they would find a job after graduation at the beginning of the group process, and this rate increased to $100 \%$ at the end of the group process. In the same way with the group work; while $71.42 \%$ of the group members thought that the period of finding a job after graduation is $12-23$ months at the beginning of the group work, at the end of this working process, $85.72 \%$ of the participants changed their mind as 0-11 months. While this result shows that group work is beneficial in reaching the purpose of the research, it is also thought that group work may have a higher effect on the participants by increasing the number of sessions.

Conclussion; As a result of the review of the related literature, it was seen that the group studies on social work discipline were not sufficient. This group work with social work department internship students 
will contribute to the field in terms of both being a social work practice with groups and being a vocational counselling practice for university students. It will be beneficial for the future motivation of students with anxiety and hopelessness to find a job. It is thought that performing group studies to be developed in this direction will support students who will start the profession in terms of providing professional self-confidence, increasing their motivation and hopes of finding a job and strengthening their professional equipment.

Keywords: Social work, anxiety, hopelessness, job search, group work

Öz: Amaç: $\mathrm{Bu}$ çalışmanın amacı sosyal hizmet bölümü stajyer öğrencilerinin iş bulma kaygılarını ve umutsuzluklarını azaltmaya yönelik grup üyeleri arasında bilgi ve beceri paylaşımında bulunularak öğrencilerin iş bulma motivasyonunun arttırılması için tasarlanan grup çalışmasının etkililiğinin denenmesidir. Yöntem: Çalışma grubunu çocuk refahı alanıyla ilgili bir kuruluşta staj yapan çeşitli üniversitelerin sosyal hizmet lisans bölümü son sınıflarında öğrenim gören 7 stajyer öğrenci oluşturmaktadır. 7 oturum olarak süren grup çalışmasının ilk oturumundan önce ve son oturumundan sonra katılımcılara Beck Umutsuzluk Ölçeği ve Durumluk- Sürekli Kaygı Ölçeği uygulanarak ön test-son test çalışması yapılmış ve grup çalışmasının etkililiği ölçülmeye çalışılmıştır. Araştırmanın verileri SPSS Statistics 22.0 programında değerlendirilmişstir. Verilerin analizinde Wilcoxon Signed Rank Testi uygulanmış ve grup çalışmasının sonunda katılımcılardan dönütler alınmıştır. Bulgular: Sosyal hizmet bölümü stajyer öğrencilerinin iş bulma kaygılarını ve umutsuzluklarını azaltmaya yönelik tasarlanan grup çalışmasının birinci oturumundan önce ve yedinci oturumundan sonra yapılan Beck Umutsuzluk Ölçeği ve Durumluk- Sürekli Kaygı Ölçeği 'ne ait ön test ve son test puanları incelendiğinde işlem öncesi ve işlem sonrası puanlarında anlamlı bir farklılık bulunamamıştır. Ancak; grup üyelerinin ölçeklere ait ön test ve son test puanlarına bakıldığında kaygı ve umutsuzluk düzeylerinde dikkate değer bir azalma söz konusu olmuştur. Sonuç: Grup çalışmasında sosyal hizmet bölümü stajyer öğrencilerinin iş bulma kaygıları ve umutsuzluk düzeylerinde işlem öncesi ve sonrası anlamlı bir farklılık bulunmasa da öğrencilerin umutsuzluk ve kaygı düzeyleri puanlarında önemli bir düzeyde azalma görülmüştür. Sosyal hizmet bölümü stajyer öğrencileriyle yapılan bu grup çalışması da hem gruplarla sosyal hizmet uygulaması olması hem de üniversite öğrencilerine yönelik yapılan bir meslek danışmanlığı uygulaması olması yönüyle alana katkı sağlayacak ve iş bulma kaygısı ve umutsuzluğu olan öğrencilerin gelecek motivasyonlarının sağlanması açısından faydalı olacaktır.

Anahtar Kelimeler: Sosyal hizmet, kaygı, umutsuzluk, iş bulma, grup çalışması

\section{Giriş}

Dünyanın en önemli sosyal sorunlarından biri olan işsizlik Türkiye için de çözülmesi gereken sorunların başında gelmektedir. Bireyler, sosyoekonomik düzeylerini arttırmak ve daha iyi iş imkanları ile yüksek gelirlere sahip olmak için üniversite okumakta hatta lisansüstü eğitim almaktadır (Taşğın, Bozgeyikli, \& Boğazlıyan, 2017). TÜİK 2019 yılı istihdam oranları verileri incelendiğinde; Türkiye'de okuma yazma bilmeyenlerin istihdam oranının $\% 24,2$, ilköğretim mezunlarının istihdam oranının $\% 54,8$, lise dengi mesleki okulların mezunlarının istihdam oranının $\% 56,9$, yükseköğretim mezunlarının ise istihdam oranının $\% 70,8$ olduğu tespit edilmiştir. Yine aynı yılın işgücüne katılım oranları verilerine bakıldığında işgücüne katılım oranlarında ilköğretim mezunlarının \%67,1, genel lise mezunlarının \%55,5, yükseköğretim mezunlarının \%82 olduğu görülmektedir (Türkiye İstatistik Kurumu, 2019). Veriler göstermektedir ki yükseköğretim mezunlarının hem istihdam oranlarının hem de işgücüne katılım oranlarının diğer öğrenim düzeylerine göre yüksek olduğudur. Bu noktada gençler işsiz kalmamak için eğitim düzeylerini bir üst dereceye yükselterek, lisans ve lisansüstü eğitimler alarak iş bulma noktasında önde olmaya çalışmaktadırlar. Ancak üniversite eğitimi almanın iş bulma sorununu tamamen çözdüğü söylenememekle beraber nitelikli ve eğitim düzeyi yüksek işsiz kesimde ortaya çıkmaktadır (Kıcır, 2010). Nitekim eğitim düzeylerine göre işsizlik oranlarına bakıldığında yükseköğretim mezunlarının işsizlik oranının da \%13,7 olduğu belirlenmiştir (Türkiye İstatistik Kurumu, 2019). Üniversite mezunları arasındaki işsiz kesimin varlığı, her geçen yıl açılan üniversite sayılarının artması, ilgili bölümlerden mezun olan öğrenci sayısının hızla yükselmesi, istihdam oranlarının azalması özellikle 
son sınıf üniversite öğrencilerini ruhsal açıdan etkilemekte ve öğrencilerde mezun olduktan sonra iş bulabilme durumuna yönelik kaygıya ve geleceklerine dair umutsuzluğa sebep olmaktadır (Dursun \& Aytaç, 2009).

Umutsuzluk, bireyin gelecekle ilgili hedeflerini gerçekleştirmek için gelecekten olumsuz beklentilerinin olduğunu ifade eden bir kavramdır. Eğer bir birey umutsuzluk duygusu yaşıyorsa gelecekteki amaçlara ulaşabilme konusunda başarısız olacağı yönünde ön yargıya sahiptir. Umut ise tam tersine geleceğe dair kişinin amacına ulaşmada beklentisinin ya da beklentilerinin olmasını ifade eder (Dilbaz \& Seber, 1993). Lord (2008) bir çalışmasında terapistlerin, müracaatçılarının zorlu yaşam hikayelerine şahit olmalarından dolayı umut ve umutsuzluk arasındaki dengenin önemini vurgulamış ve bu denge sayesinde müracaatçılarla çalışabildiklerine değinmiştir. Kaygı ise insanda var olan diğer temel duygulardan biridir ve bu kaygı duygusunun belirsiz bir korkudan kaynakladığı varsayılmaktadır. Bu duygu tıpkı korku duygusu gibi insanda bir savunma mekanizması olarak görülmekte insanın kendisini tehlikeden koruması amacıyla kullandığı bir duygu olarak tanımlanmaktadır. Eskiden doğal afetler ve olaylar bir kaygı kaynağı olarak görülürken günümüzde kaygıya sebep olan pek çok faktörün olduğu yapılan araştırmalarla ortaya konulmuştur (Taşpınar Göveç \& Başgül, 2017). Spielberger ve arkadaşları (1983) kaygıyı durumluk ve sürekli olarak açıklamıştır. Durumluk kaygı bireyin içinde bulunduğu anlık duygusal durumdan kaynaklanma olarak ifade edilirken, sürekli kaygı ise stresli anlarda kaygı ile reaksiyona girme eğilimi olarak tanımlanmaktadır (Spielberger, Jacobs, Russell, \& Crane, 1983).

Üniversite son sınıf öğrencilerinde mezun olduktan sonra iş bulmaya yönelik kaygı ve umutsuzluk duygularının yaşandığı bölümlerden biri de sosyal hizmet disiplinidir. Sosyal hizmet; insanların sorunların üstesinden gelebilme, problemleri çözebilme kapasitelerini geliştirmelerine ve sosyal işlevselliklerini arttırma noktasında bireylere, gruplara ve topluluklara yardım etmeyi amaçlayan kendi bilgi, beceri ve değer seti olan uygulamalı bir meslektir (Zastrow, 2010). Sosyal hizmetin;

- İnsanların toplumsal işlevselliğini geliştirmek,

- İnsanlar arasındaki sosyal ilişkilerin niteliğini arttırmak,

- Ezilen ve hassas durumda olup risk altında bulunan grupları güçlendirmek,

- İnsanların temel gereksinimlerinin sağlanmasında yardımcı olmak,

- Toplumdaki işsizlik, yoksulluk, suçluluk ve sosyal dışlanma gibi sosyal sorunları çözmek gibi bazı amaçları vardır (Sheafor ve Horejsi, 2016; Gökçearslan Çiftçi ve Gönen, 2011; Danış, 2007).

Sosyal hizmet mesleğini yürüten sosyal hizmet uzmanları/ sosyal çalışmacılar birçok sosyal hizmet alanında çalışmakta, kamu kurum ve kuruluşlarında, sivil toplum örgütlerinde görev almaktadırlar. Bu kurum ve kuruluşlar; Aile, Çalışma ve Sosyal Hizmetler Bakanlığı'na bağlı çocuk evleri, çocuk evleri sitesi, kadın konukevleri, huzurevleri, engelli bakım ve rehabilitasyon merkezleri, sosyal hizmet merkezleri, Adalet Bakanlığı'na bağlı adli destek müdürlükleri, cezaevleri, denetimli serbestlik müdürlükleri, Sağlık Bakanlığı'na bağlı hastaneler, kaymakamlıklara bağlı sosyal yardımlaşma ve dayanışma vakıfları, belediyeler, Gençlik ve Spor Bakanlığı'na bağlı öğrenci yurtları, çeşitli sivil toplum örgütleri gibi sosyal hizmet uygulamaları ve sosyal hizmet müdahalelerinin gerçekleştirildiği bazı sosyal hizmet kurum ve kuruluşları olarak karşımıza çıkmaktadır (Işıkhan, Erbay, Akçay, \& Ege, 2016). Çocuk, engelli, kadın, yaşlı gibi refah alanları, göçmenlerle sosyal hizmet, psikiyatrik sosyal hizmet, tıbbı sosyal hizmet, klinik sosyal hizmet, adli sosyal hizmet gibi farklı sosyal hizmet alanlarında kendi kuramsal bilgisi doğrultusunda uygulamalı 
olarak çalışan sosyal hizmet uzmanlarının yetiştirilmesinde sosyal hizmet eğitimi noktasında 2000'li yıllardan itibaren önemli gelişmeler yaşanmıştır. Sosyal hizmet eğitimi veren bölüm sayısı uzun yıllardan sonra birken (Hacettepe Üniversitesi Sosyal Hizmet Bölümü) 2002 y1lında Başkent Üniversitesi Sosyal Hizmet Bölümünün açılmasıyla iki olmuş ve 2015 yılında ise sosyal hizmet bölümü sayıs1 66'ya çıkmıştır (Alptekin, Topuz, \& Zengin, 2017).

2011 yılında sosyal hizmet eğitimi veren bölümlerin sayısının hızla yükselmesi, açık öğretim programlarının da açılmasıyla öğrenci kontenjanlarının artması ve mezun öğrencilerin istihdamına yönelik alanın daralması nedeniyle sosyal hizmet bölümü öğrencilerinde iş bulabilme kaygısı yaşayacakları algısı gelişmeye başlamıştır (Alptekin, Topuz, \&Zengin, 2014; Işıkhan, Erbay, Akçay, \& Ege, 2016). Nitekim 2019 y1lına gelindiğinde de üniversitelerin sosyal hizmet bölümlerinde 20192020 akademik eğitim yılında öğrenim gören toplam öğrenci sayısının 32.714 olduğu, 2019 yılında ise sosyal hizmet lisansı bölümlerinden 5945 öğrencinin mezun olduğu görülmektedir (Yükseköğretim Bilgi Yönetim Sistemi, 2020). Sosyal hizmet bölümü öğrencilerinin mesleğe dair gelecek kaygılarını ölçmek amacıyla yapılan araştırmada da öğrencilerin gelecek kaygılarının olduğu ve meslekle ilgili istihdam olanaklarını da yeterli görmedikleri tespit edildiği, eğer gerekli önlemler alınmazsa ilerleyen yıllarda öğrencilerin gelecek kaygılarının artacağının düşünüldüğü belirtilmiştir (Sevim \& Altun, 2017).

Üniversite öğrencilerinin mesleğe dair iş bulma kaygıları ve umutsuzluklarına dair araştırmaların genel olarak öğretmenlik, iktisadi ve idari bilimler, sağlık bilimleri gibi bölümlerde yapıldığı görülmüştür (Demir ve Taşkıran, 2018; Üstün ve diğerleri, 2014; Şanlı K. ve Saraç, 2017; Tekin Tayfun ve Korkmaz, 2016; Dursun ve Aytaç, 2009; Demir, 2016; Küçük, Usta ve Torpuş, 2019; Erdoğan ve Akın, 2016; Taşğın, Bozgeyikli ve Boğazlıyan, 2017). Diğer taraftan sosyal hizmet disiplini alanında yapılan çalışmaların doğrudan öğrencilerin iş bulma kaygıları ve umutsuzluklarına dair çalışmalar olmadığı, mevcut araştırmalarında genel olarak sosyal hizmet uzmanlarının istihdam durumu, gelecek planları, sosyal hizmet eğitimi üzerine olduğudur (Topuz ve Öz, 2014; Iş1khan, Erbay, Akçay, \&Ege, 2016; Sevim ve Altun, 2017; Alptekin, Topuz ve Zengin, 2017; Başer, 2018). Bu açıdan bakıldığında; diğer bölümlerde çeşitli örneklem gruplarıyla yapılan araştırmaların genellikle öğrencilerin iş bulma kaygılarını ve umutsuzlukları düzeyini saptamaya ve bunları etkileyen faktörleri belirlemeye yönelik nicel ve nitel çalışmalar şeklinde olduğu; sosyal hizmet disiplinine dair araştırmaların ise derleme ya da nicel yöntemler kullanarak yapıldığ görülmektedir. Özetle; öğrencilerin iş bulma kaygısı ve iş bulma noktasında umutsuzluklarına ilişkin yapılan araştırmaların bu durumu saptama çalışmalarından öteye geçmediği, sosyal hizmet disiplininde de bu konuyla ilgili doğrudan bir çalışma yapılmadığ 1 yorumlaması yapılabilir. Bu durum göstermektedir ki öğrencilerin iş bulma kaygısını ve geleceğe yönelik umutsuzluk düzeylerinin azaltılmasına ve öğrencilerin iş bulma motivasyonlarının güçlendirilmesine, öğrencilere bu noktada psikososyal destek verilmesine ve öğrencilere mesleki danışmanlık sağlanmasına ve bu çalışmaların etkililiğinin sınanmasına yönelik deneysel çalışmaların yapılmasına ihtiyaç oluşturmaktadır.

2011 yılından itibaren sosyal hizmet bölümü mezunlarının sayısının hızla yükselmesi, açılan bölümlerde okuyan öğrenci sayısının artması, sosyal hizmet uzmanlarının istihdam olanaklarının azalması, kamuya atanma KPSS puanlarının yükselmesi, yükseköğretim mezunlarının işsizlik oranlarının düzeyi sosyal hizmet bölümlerinde okuyan öğrencilerin geleceğe dair bakış açılarını etkilemekte ve öğrencilerde iş bulma noktasında kaygıya ve umutsuzluğa yol açmaktadır. İlgili literatür incelendiğinde; sosyal hizmet bölümlerinde okuyan öğrencilerin iş bulma kaygısı ve umutsuzluk düzeyini ölçmeye yönelik herhangi bir çalışmaya rastlanılmaması ve sosyal hizmet bölümü mezunlarının istihdam durumlarına yönelik yapılan araştırmaların da çok az sayıda olması bu araştırmanın gerekliliğini ortaya koymuştur.

\section{Araştırmanın Amacı}


$\mathrm{Bu}$ araştırmada grup çalışması yöntemiyle, sosyal hizmet bölümü stajyer öğrencilerinin iş bulma kaygısı ve umutsuzluk düzeylerini azaltmaya yönelik grup üyeleri arasında bilgi ve beceri paylaşımında bulunularak öğrencilerin iş bulma motivasyonunun güçlendirilmesi, sosyal hizmet mesleği ve iş olanaklarıyla ilgili bilgilerinin arttırılıp iş bulma kaygısıyla başa çıkma yeteneklerinin geliştirilmesi amaçlanmıştır.

Kongar (1978) ve Zastrow (2010)'a göre grup çalışması; karş11ıklı yüz yüze etkileşim içinde olup aralarındaki pozitif bağlılığın farkında olan, ortak bir amaç için bir araya gelen bireylere gruplar yoluyla yardım ederek bireylerde istenen değişiklikleri oluşturma sürecidir. Yapılan grup çalışmasıyla araştırmanın alt amaçları şunlardır:

- Sosyal hizmet bölümü stajyer öğrencilerinin iş bulma kaygılarını ve umutsuzlukları azaltmaya yönelik paylaşımlarda bulunularak öğrencilerin motivasyonunun arttırılması,

- Sosyal hizmet bölümü stajyer öğrencilerinin mesleklerini icra edebilecekleri çalışma alanlarının neler olabileceği üzerine paylaşımlar yapılarak grup üyelerinin bilgilendirilmesinin sağlanması ve bilgi eksikliklerinin giderilmesi,

- Öğrencilerin devlet kurumlarının dışında çalışabilecekleri özel kurumlar ve sivil toplum örgütleri gibi kuruluşların nereler olduğu hakkında bilgi paylaşımı yapılması,

- Sosyal hizmet kurum ve kuruluşlarında çalışacak sosyal hizmet uzmanlarının hangi bilgi ve becerilere sahip olması gerektiği üzerine tartışma yapılarak öğrencilerin bilgilendirilmesi,

- Bir sosyal hizmet uzmanının mezun olmadan önce alabileceği takviye eğitimler, kurslar vb. faaliyetlerin neler olabileceği üzerine konuşulması,

- Gruptaki her üyenin kendi mesleki bilgi ve becerisinin farkında olmasını sağlanması, kariyer planlaması yapabilmesine yardımcı olunması,

- Katılımcilara meslek hayatında kullanabilecekleri gruplarla sosyal çalışma becerisi kazandırılması, grup süresince yapılacak oyun etkinlikleriyle katılımcıların girişkenliği ve motivasyonlarının arttırılması,

- Katılımcıların nerelerde iş bulabileceğine yönelik araştırma yapabilme, doğru bilgiye ulaşabilme becerilerinin geliştirilmesi şeklindedir.

\section{Araştırmanın Önemi}

Sosyal hizmet bölümü son sınıf stajyer öğrencilerin iş bulma kaygısını azaltmaya yönelik bu çalışma, öğrencilerin kaygı ve umutsuzluk düzeylerinin belirlenmesinin ötesinde; yapılacak grup çalışmasıyla öğrencilerin iş bulmaya yönelik kaygı ve umutsuzluklarını azaltmayı ve iş bulma noktasında motivasyonlarını arttırmayı hedeflemesi bakımından deneysel olması ve bu konudaki ilk grup çalışması olması yönüyle önem taşımaktadır.

\section{Yöntem}

\section{Araştırmanın Modeli}

Sosyal hizmet bölümü stajyer öğrencilerinin iş bulma kaygılarını ve umutsuzluklarını azaltmaya yönelik bilgi ve beceri paylaşımında bulunularak öğrencilerin iş bulma motivasyonunun arttırılması için tasarlanan grup çalışmasını etkililiğini sınamak amacıyla bu araştırmada kontrol 
grupsuz ön test-son test deneysel desenden yararlanılmıştır. Deneysel desende amaç değişkenler arasındaki neden-sonuç ilişkisini test etmeye dayalıdır (Büyüköztürk, Kılıç Çakmak, Akgün, Karadeniz, \& Demirel, 2008). Kontrol grupsuz olan bu grup çalışmasında kişisel bilgi formu ve iki ölçek kullanılmış olup her ölçeğin ön test ve son test çalışması yapılmıştır. Yapılan ön testin ardından, $75^{\prime}$ er dakikalık 7 oturumdan oluşan ve yedi hafta süren grup çalışması gerçekleştirilmiş, çalışmanın amacına ulaşıp ulaşmadığı son test analizleri ile sınanmıştır.

\section{2.Çalışma Grubu}

Bu araştırmanın çalışma grubunu 2018-2019 akademik yılı bahar döneminde, çocuk refahı alanıyla ilgili bir kamu kuruluşunda staj yapmakta olan çeşitli üniversitelerin sosyal hizmet bölümü son sınıfında öğrenim gören ve çalışmaya gönüllü olarak katılan 7 öğrenci oluşturmaktadır. Stajyer olarak ilgili kuruluşta görev yapan öğrencilerle ön görüşme yapılmış ve her öğrenciye grup çalışmasının konusuyla ilgili bilgi verilmiş ve her katılımcı grup çalışmasına katılmak için gönüllü olmuştur. Grup çalışmasının yedi oturumdan oluşması tasarlanmıştır. Bu çalışmada grup üyelerinin farklı üniversitelerden olması da grup çalışmasının amacına ulaşması açısından önemlidir Ayrıca grup çalışması sürecine katılan 7 ögrenci daha önce üniversitede "Gruplarla Sosyal Hizmet" dersi almasına rağmen herhangi bir grup çalışmasına katılım göstermemiştir.

\begin{tabular}{|l|l|l|}
\multicolumn{3}{|c|}{ Çizelge 1: Grup Üyelerinin Sosyo-Demografik Özellikleri } \\
\hline Yaş & Cinsiyet & Üniversite \\
\hline 22 & Kadın & İstanbul Aydın Üniversitesi \\
\hline 28 & Kadın & Anadolu Üniversitesi \\
\hline 21 & Kadın & Biruni Üniversitesi \\
\hline 23 & Kadın & Erzincan Binali Yıldırım Üniversitesi \\
\hline 21 & Erkek & Medipol Üniversitesi \\
\hline 22 & Kadın & Biruni Üniversitesi \\
\hline 22 & Kadın & İstanbul Üniversitesi- Cerrahpaşa \\
\hline
\end{tabular}

\section{Veri Toplama Araçları}

$\mathrm{Bu}$ çalışmada araştırmacılar tarafindan düzenlenen grup çalışması öncesi değerlendirme formu ve grup sonrası değerlendirme formu" olarak kullanılan "Kişisel Bilgi Formu", "Beck Umutsuzluk Ölçeği” ve "Durumluk- Sürekli Kaygı Ölçeği” kullanılmıştır.

\subsection{Kişisel Bilgi Formu}

Grup çalışması sürecinde yer alan grup üyelerinin yaş, cinsiyet, sosyal hizmet bölümünü isteyerek ya da istemeyerek tercih etme durumları, mezun olduktan sonra iş bulabilme ümitleri, mezun olduktan sonra iş bulabileceğini ümit etme süresi ile okuduğu bölümle ilgili mesleki kariyer rehberliği alıp almadığıyla ile ilgili bilgileri içeren altı sorudan oluşmaktadır. Kişisel Bilgi Formu grup çalışmasının başında grup üyelerine grup öncesi değerlendirme, grup sürecinin sonunda da grup üyelerine grup sonrası değerlendirme formu olarak uygulanmıştır.

\subsection{Beck Umutsuzluk Ölçeği}

Beck, Weissman, Lester ve Trexler (1974) tarafindan geliştirilen ve Seber (1991) ve Durak (1994) tarafından geçerlilik ve güvenirlilik çalışmaları yapılan Beck Umutsuzluk Ölçeği 11'i doğru 9'u yanlış anahtar yanıtı olan 20 maddeden oluşmaktadır. Ölçeğin yanıtlamasında katılımcıdan kendisine uygun olan seçenek için "Evet" kendisine uygun olmayan ifadeler için "Hayır" cevabını işaretlemesi beklenmektedir. Ölçekteki maddelerden 2, 4, 7, 9, 11, 12, 14,16, 17, 18 ve 20'nci sorulara verilen yanıt evet ise 1 puan $1,3,5,6,8,10,13,15$ ve 19'uncu sorulara verilen yanit hayır ise 1 puan verilmektedir. Ölçekten alınabilecek puan 0-20 arasında değişmekte olup ölçekten alınan 
toplam puan "Umutsuzluk Puanı" olarak nitelendirilmektedir (Seber, Dilbaz, Kaptanoğlu, \& Tekin, 1993). Ayrıca ölçekten alınan puanın yüksekliği umutsuzluk düzeyinin de yüksek olduğuna işaret etmektedir.

Beck ve Steer (1988) denekleri yanıtlarına göre dört grup içinde sınıflandırmış ve 0 ile 3 puan arası umutsuzluğun tamamen olmadığını, 4 ile 8 puan arası hafif umutsuzluk olduğunu, 9 ile 14 puan arası orta seviyede umutsuzluk olduğunu, 15 ile 20 puan arası ileri derecede umutsuzluk olduğunu belirtmişlerdir (Duman, Taşğın, \& Özdağ, 2009).

\subsection{Spielberger Durumluk- Sürekli Kaygı Ölçeği}

Spielberg ve arkadaşları (1964) tarafından bireylerin durumluk ve sürekli kaygı düzeylerini ölçmek amacıyla geliştirilen ölçeğin Türkçe geçerlilik ve güvenirlik çalışmaları Öner ve Le Compte (1983) tarafından yapılmıştır. 40 maddeden oluşan kendini değerlendirme türünde bir ölçek olan Durumluk ve Sürekli Kaygı Ölçeği 4'lü likert tipinde hazırlanmış birbirinden bağımsız 20'şer maddelik iki ölçekten oluşmaktadır. Durumluk kaygı alt ölçeği bireyin belirli bir zamanda veya durumda nasıl hissettiğiyle ilgiliyken sürekli kaygı alt ölçeği ise bireyin içinde bulunduğu durumu genel olarak kaygılı ve stresli algılama durumudur. Ölçeğin içinde bulunan ters maddelerdeki puanlar normale çevrildiği takdirde her madde 1 ile 4 arasında puan almakta ve yüksek puan da yüksek kaygı düzeyini göstermektedir. Her iki ölçekten elde edilen puanlar olarak 20 ile 80 puan arasında farklılık göstermekte olup büyük puan yüksek kaygı seviyesini, küçük puan düşük kaygı seviyesini belirtmektedir.

\section{Verilerin Analizi}

"Beck Umutsuzluk Ölçeği” ve "Durumluk- Sürekli Kaygı Ölçeği” ile yapılan ön test ve son test uygulamalarının ardından elde edilen veriler bilgisayar ortamında SPSS Statistics 22.0 istatistik programında analiz edilmiştir. Verilerin analizinde parametrik olmayan Wilcoxon Signed Rank testi kullanılmıştır.

\section{Grup Oturumlarının Özeti}

Bu grup çalışmasının amacı çeşitli üniversitelerde eğitim gören sosyal hizmet bölümü stajyer öğrencilerinin iş bulma kaygılarını azaltmaya çalışmakla birlikte, kariyer planlamaları yapmalarına yardımcı olabilecek paylaşımlarda bulunulmasını sağlamaktır. Bu amaçla İstanbul'da bulunan çocuk refahı alanında hizmet veren bir kuruluşta bulunan çeşitli üniversitelerin son sınıf stajyer öğrencilerinden yedi katılımcı ile 2018-2019 akademik yılı bahar döneminde İstanbul Üniversitesi Cerrahpaşa Sağlık Bilimleri Fakültesi Yüksek Lisans dersliğinde yedi oturum sürecek şekilde grup çalışması gerçekleştirilmiştir.

\section{Birinci oturum}

Birinci oturumun temel amacı grup üyelerinin grup çalışmasının konusu ve amacı hakkında bilgi sahibi olmasını sağlamaktır. Grup kurallarının belirlenmesi, grup üyelerinin birbirlerini tanıması ve grup çalışmasının konusu üzerine grup üyelerinin beklentilerinin alınması da oturumun diğer amaçlarındandır. Birinci oturum, iki farklı tanışma etkinliği yapılarak çeşitli üniversitelerde öğrenim gören öğrencilerin birbirleriyle tanışmaları sağlanarak başlamış ve grup üyelerine grubun amacını açık hale getirmek için grubun konusu ve alt amaçları anlatılarak devam etmiştir. Grubun alt amaçları grup üyelerine aktarıldıktan sonra grup oturumlarının içeriğini oluşturacak konular üzerine grup üyeleriyle paylaşımlarda bulunulmuştur. Katılımcılarla sosyal hizmet uzmanlarının istihdam durumu, katılımcıların yaşadıkları iş bulma kaygıları, sosyal hizmet uzmanların çalışma alanları üzerine konuşulmuştur. Grup üyelerinin mesleki açıdan sahip olmaları gereken bilgi ve becerilerle kendi kariyerlerine katk1 sağlayabilecek eğitimler, kurslar üzerine gruba genel bilgi verilmiş, grup çalışmasının amacına uygun olarak ekleme yapmak isteyenlerin düşünceleri alınmıştır. Grubun amacı, içeriği ve gruptan beklentiler üzerine paylaşımlar yapılmış ve grup 
çalışması uygulama süresince dikkat edilmesi gereken kuralların oluşturulması aşamasına geçilmiştir. Grup üyelerinin grup kurallarıyla ilgili görüşlerinin alınıp grup üyeleriyle birlikte grup süreci kuralları belirlenmiştir.

Birinci oturum; ilk oturumun özetlenmesi, grup üyelerinin değerlendirmelerinin alınması ve gelecek oturum için planlanan konunun konuşulması ve ev ödevi verilmesiyle sonlanmıştır. Birinci oturuma genel olarak bakıldığında grup üyelerinin tanışması için etkinlikler yapılmış, grubun konusu, amacı ve grubun içeriği konusunda grup üyeleri bilgilendirilmiş ve grup çalışmasından beklentiler üzerine katılımcılar arasında paylaşımlarda bulunulmuştur.

\section{İkinci Oturum}

İkinci oturumla çocuk refahı alanında sosyal hizmet uzmanlarının çalışabileceği kurumların nereler olabileceği, bu alanda çalışmak isteyen kişilerin hangi bilgi ve beceri donanımına sahip olması gerektiği ve çocuk refahı alanında yetkinlikleri ile niteliklerini güçlendirmeye yönelik nasıl eğitimler alabilecekleri üzerine bilgi paylaşımı yapılarak grup üyelerinin bilgi seviyelerini arttırması amaçlanmıştır.

İkinci oturumda, grup lideri tarafindan grup üyelerine ilk oturumda neler yapıldığıyla ilgili soru sorulmuş ve katılımcılardan birinin özetlemesi istenmiştir. Geçen oturumun özetinin yapılmasından sonra grup üyelerinin sürece 1sınmaları için "karışık salata" oyunu oynanmıştır. Karışık salata isimli etkinlikle katılımcıların dikkatinin toparlanması ve grup içi dinamiklerin pekiştirilmesi amaçlanmıştır. Grup lideri 1sınma etkinliğinden sonra; grup üyelerine verilen ev ödevine istinaden çocuk refahı alanıyla ilgili çalışabilecekleri kurumların bilgisini tur olacak şekilde paylaşmalarını istemiştir. Oturumun sonuna doğru grup üyelerinden oturumun nasıl geçtiği, beklentileri, eksik buldukları noktalar ya da önerileri üzerine düşünceleri alınmıştır. İkinci oturum; oturumun özetlenmesi, grup üyelerinin değerlendirmelerinin alınması ve gelecek oturum için planlanan konunun konuşulması ve ev ödevinin verilmesi ile sonlanmıştır.

İkinci oturumda grubun konusu ve amacından kısaca bahsedilmiş, birinci oturumda neler yapıldığı üzerine konuşulmuştur. Sonraki süreçte çocuk refahı alanında iş bulunabilecek kurumlar, çalışma şartları, kurumların istihdam durumları ve buralarda çalışacak sosyal hizmet uzmanını mesleki açıdan önde kılacak hangi donanımlara sahip olunması gerektiği üzerine bilgi paylaşımı yapılmıştır.

\section{Üçüncü Oturum}

Üçüncü oturumla çocuk refahı alanında grup üyelerini farklı kılacak, özgeçmişlerini ve mesleki becerilerini güçlendirecek eğitimlere, kurslara nerelerden ulaşabilecekleri ve bu eğitimi hangi kurumların verdiği noktasında grup üyeleriyle bilgi paylaşımı sağlanması amaçlanmıştır. Ayrıca; mültecilere hizmet sunan hangi sosyal hizmet kurum ve kuruluşlarının olduğu, bu kurumların sosyal hizmet uzmanı istihdam edebilme durumu ve işe başvuruda grup üyelerini önde kılacak donanımların neler olması gerektiği ve mültecilerle sosyal hizmet alanında çalışabilecekleri kurumlar, kurumların başvuru koşulları, örnek iş ilanları gibi konularda oturumda bilgi paylaşımında bulunup katılımcıların bilgi seviyesinin arttırılması amaçlanmıştır.

Üçüncü oturum; grup liderinin grup üyelerinden ikinci oturumun özetlenmesini istemesiyle başlamıştır. Oturumun özetinin yapılmasından sonra grup üyelerinin sürece ısınmaları için "sıcak sandalye" oyunu oynanmıştır. Sıcak sandalye isimli etkinlikle katılımcıların dikkatinin toparlanması ve grup içi dinamiklerin pekiştirilmesi amaçlanmıştır. Grup lideri ısınma etkinliğinden sonra; grup üyelerine verilen ev ödevine istinaden çocuk refahı alanıyla ilgili alabilecekleri eğitimlerin bilgisini tur olacak şekilde paylaşmalarını istemiştir. Çocuk refahı alanına ilişkin bilgi paylaşımı yapıldıktan sonra diğer konuya geçmeden grup üyeleriyle yaratıcı drama etkinliği yapılmıştır. Etkinlikte katılımcılara tur olacak şekilde cümleler söylenmiş ve kendilerini bu durumda hayal etmeleri istenmiş ve "Anlat bakalım ne hissediyorsun?" etkinliği yapılmıştır. Yapılan etkinliklerden sonra 
grup üyelerinin dikkati toplanmış ve mültecilerle sosyal hizmet bağlamında verilen ev ödevlerinin paylaşılması grup üyelerinden istenmiştir.

Üçüncü oturumun esas konusu olan çocuk refahı alanına ilişkin alınabilecek eğitimler konusunda derinlemesine bilgi paylaşımı yapılmış ve mültecilerle çalışan sivil toplum örgütlerinden örnekler verilmiştir.

\section{Dördüncü Oturum}

Dördüncü oturumla kadın refahı, tıbbi sosyal hizmet, adli sosyal hizmet alanına sosyal hizmet uzmanı istihdam eden sivil toplum örgütleri ve kamu kurumları hakkında grup üyeleri ile bu alanlarda yapılan çalışmalara dair karşılıklı bilgi alışverişi yapılması ve bu alanlardaki iş̧ imkânlarının varlığının araştırılması amaçlanmıştır. Ayrıca sivil toplum kuruluşlarının, devlet kurumlarının vermiş oldukları iş ilanı örneklerinin araştırılıp grup üyeleriyle paylaşılması ve işe alımlarda sosyal hizmet uzmanında aranan niteliklerin neler olduğu üzerine grup üyelerini bilgilendirmede yine bu oturumun amaçları arasında yer almıştır.

Dördüncü oturum grup lideri tarafından grup üyelerine üçüncü oturumda neler yapıldığıyla ilgili soru sorulmuş ve katılımcılardan birinin üçüncü oturumu özetlemesi istenerek başlamıştır. Grup üyesinin üçüncü oturumu özetlemesinin ardından grup lideri, katılımcılara "sandalye kapmaca" oyununu oynayacaklarını söylemiş ve bu oyunla üyelerin oturum sürecine ısınmaları amaçlanmıştır. Oyunun ardından üyelerden yerlerini almaları istenmiş ve oturum sürecine grup çalışmasının bu haftaki amacı ve grup çalışmasının konusu üzerine kısa bir giriş yapılarak başlanmıştır. Grup lideri daha sonrasında grup üyelerinden araştırmalarını yaptıkları sosyal hizmet istihdam alanlarıyla ilgili sırasıyla bilgilerini paylaşmalarını istemiştir. Oturum; dördüncü oturumun özetlenmesi, grup üyelerinin değerlendirmelerinin alınması ve gelecek oturum için planlanan konunun konuşulması ve ev ödevinin verilmesiyle sonlanmıştır.

\section{Beşinci Oturum}

Beşinci oturumla engelli ve yaşlı hizmetleri alanında sosyal hizmet uzmanlarının çalışabileceği sivil toplum kuruluşları ile kamu kurumlarının neler olduğu, bu alanlarda faaliyet gösteren sivil toplum kuruluşlarının yayınladığı iş ilanlarında hangi niteliklere sahip sosyal hizmet uzmanı aradıkları üzerine grup üyeleriyle bilgi alışverişi yapılarak grup üyelerinin bu alanlara dair bilgi seviyelerinin arttırılması amaçlanmıştır.

Grup lideri, grubun oturum sürecine başlamadan önce grup üyelerinin dikkatlerini toplamaları adına elinde yumak haline getirdiği kâğıdı grup üyelerine göstererek bu topu rastgele birbirlerine atmalarını ve topu alan kişinin de kimsenin bilmediği bir özelliğini grupla paylaşmasını istemiştir. Kendilerine gelen topu alarak özelliklerini paylaşan üyelerin bu etkinliği iki tur olarak sürdürmelerinin ardından etkinlik grup lideri tarafından sonlandırılmıştır. Grup üyelerinin hareketlendirilmesi adına ikinci bir etkinlik olarak "Gemi Batıyor" oyunu oynanmıştır. Oyunun grup lideri tarafından sonlandırılmasıyla beraber grup çalışmasının geçen haftaki oturumunda hangi konuların konuşulduğu grup üyeleri tarafından birer cümleyle özetlenmiş ve bu haftaki paylaşım yapılacak konuların neler olduğuna dair hatırlatmayla grup süreci başlamıştır. Grup lideri, grup üyelerine verilen ev ödevine istinaden yaşlı ve engelli hizmetleri alanıyla ilgili çalışabilecekleri kuruluşları ve iş ilanlarını tur olacak şekilde paylaşmalarını istemiştir. Beşinci oturum; oturumun özetlenmesi, katılımcılarının değerlendirmelerinin alınması ve gelecek oturum için konuşulacak konuların verilmesiyle sonlandırılmıştır.

Beşinci oturumda; genel olarak yaşlı ve engelli hizmetleri alanında hizmet veren kurum ve kuruluşlar ile Sosyal Yardımlaşma ve Dayanışma Vakıfları'nın iş imkânları, aranan sosyal hizmet uzmanının niteliklerinin neler olduğu ve işe alım ilanlarına dair konular hakkında bilgi paylaşımında bulunulmuştur. 


\section{Altınci Oturum}

Altıncı oturumla grup üyelerinin akademik kariyer konusuna dair fikirleri üzerinden bir çerçeve çizip lisansüstü eğitim ile ALES ve YDS gibi sınavlar konusunda bilgilendirme yapılmıştır. Katılımcıların diğer sosyal hizmet mezunlarından iş bulma ve kariyer planlama bilgi ve becerisi açısından farklı olmalarını ve iş bulma şanslarını artıracak alanlara yönelmelerinin sağlanması amaçlanmıştır. Grup lideri tarafından katılımcıların motivasyonlarını arttırmak adına "sandalye kapmaca" oyunu oynanmıştır. Oyunun sonlandırılmasının ardından grup lideri katılımcıların genel olarak nasıl olduklarını ve neler yaptıklarını sormuştur. Grup üyelerinin cevaplarından sonra grup lideri bu haftaki oturumda sosyal hizmet alanında akademiye dair paylaşım yapacağını söylemiş ve kimlerin sosyal hizmette lisansüstü eğitim yapmayı düşündügünü ve yüksek lisans/ doktora eğitimi alabilmek için hangi şartların sağlanması gerektiğini, yurtdışı eğitim fırsatlarının neler olabileceğini sormuştur.

Altıncı oturum; oturumun kısa özeti, grup üyelerinin değerlendirmeleri ve gelecek oturumda konuşulacak konuların ifade edilmesiyle sona ermiştir. Altıncı oturuma genel olarak bakıldığında akademik kariyer, yüksek lisans, doktora eğitimi için gerekli şartların neler olduğu, hangi sınavlara girilmesi gerektiği, alınması gereken ortalama puanlara dair konuşmalar yapılmıştır.

\section{Yedinci Oturum}

Yedinci oturumla; grup üyeleriyle yapılan altı oturumun değerlendirilmesi, yapılan grup çalışmasının katılımcılarda ne gibi değişikliklere yol açtığına dair görüşlerin alınması amaçlanmıştır. Grup lideri tarafindan katılımcıların dikkatlerini toplamak ve motivasyonlarını canlandırmak adına 1sınma etkinliği oynanmıştır. Yedinci oturumda, altınca oturumun kısa bir özeti yapılmış, 1sınma oyunu oynanmış ve grup üyelerinin ilk altı oturumla ilgili yani grup süreci ile ilgili görüşleri alınmış, neler hatırladıkları sorulmuş duygu ve düşünceleri alınmıştır. Bu oturumun grubun sonlandırılması oturumu olması sebebiyle grup üyelerinden grup çalışmasının kendileri için hayatında neleri değiştirdiğini görebilmek adına düşünceleri sorulmuştur. Yedinci oturumun sonunda son olarak da katılımcılara grup çalışmasının başında doldurdukları ölçekler tekrar dağıtılarak ve son test çalışması yapılmıştır.

\section{Bulgular}

$\mathrm{Bu}$ bölümde araştırmanın bulgularına yer verilmiştir. Grup çalışmasına katılan grup üyelerinin $\% 85,72$ 'si kadın, $\% 14,28$ 'i erkektir. Grup üyelerinin yaş ortalaması 22,7 olup grup üyelerinin \%71,42'si bölümü isteyerek tercih etmiş ve grup üyelerinin hiçbiri daha önce mesleğiyle ilgili kariyer rehberliği almamıştır. Grup çalışması başlamadan önce grup üyelerine uygulanan kişisel bilgi formunda yer alan mezun olduktan sonra iş bulabileceğini umut etme durumuna katılımcıların $\% 71,42$ 'si hayır derken, mezun olduktan sonra iş bulabileceğini ümit ettiği süreye ise katılımcıların $\% 14,28$ 'i 24 ay ve üstü, $\% 14,28$ 'i 0-11 ay, \%71,42'si $12-23$ ay olacak şekilde cevap vermiştir. Grup çalışması tamamlandıktan sonra uygulanan grup sonrası değerlendirme formunda yer alan mezun olduktan sonra iş bulabileceğini umut etme durumuna katılımcıların \%100'ü evet derken, mezun olduktan sonra iş bulabileceğini ümit ettiği süreye ise katılımcıların \%85,72'si $0-11$ ay, \%14,28'i ise 12-23 ay olarak cevap vermiştir.

Grup lideri, son oturumda gerçekleştirilen etkinlikte grup çalışmasının grup üyelerine katkısını sormuş ve süreci birer cümleyle özetlemelerini istediğinde ise katılımcılar şu şekilde cevaplar vermiştir:

- “İ̧ bulma noktasında kendimi cesaretli görüyorum.” (K1)

- “İ̧s kaygısından çok kendimi geliştirmeyi öğrendim. ” (K2)

- “Mesleki kaygı düzeyimi en aza indirmeyi ögrendim.” (K3) 
- “Aydınlığa doğru bir yol görmekle birlikte iş kaygım bitmiştir." (K4)

- "Grupla çalışabilme cesaretini ögrendim, iş bulabileceğime inandım.” (K5)

- "Eskiden karamsarken şimdi umutluyum, karanlıktan aydınlı̆̆a geçtim." (K6)

- "Nerede olursam olayım sizi rol model alacağım ve bu grup çalışmasıyla kendimi alanda çok avantajll görüyorum." (K7)

Grup üyelerinin verdiği cevaplar grup çalışmasının kendileri için olumlu geçtiğini göstermektedir.

Katılımcılara uygulanan ölçeklere ilişkin grup çalışmasının ilk oturumu ile son oturumuna ait farklar incelenmiştir. Test işleminin gerçekleştirilebilmesi için Beck Umutsuzluk, Durumluk ve Sürekli Kaygı ölçeklerinden elde edilen puanlar her bir katılımcı için tek tek işlemden öncesini ve sonrasını temsil edecek şekilde hesaplanmıştır. İlgili testler I.tip hata 0.05 olacak şekilde gerçekleştirilmiştir. İlgili puanların karşılaştırılabilmesi için örnek çapının küçük olması nedeniyle t-testinin parametrik olmayan karşıllı̆ı Wilcoxon Signed Rank test seçilmiş ve bu bağlamda SPSS üzerinde ilgili işlemler uygulanmış ve çıktılar aşağıdaki gibi elde edilmiştir;

Tablo 1: Beck Umutsuzluk Ölçeği, Durumluk- Sürekli Kaygı Ölçeğine İlişkin Wilcoxon Analizi Sonu

\begin{tabular}{|c|c|c|c|c|c|}
\hline \multicolumn{6}{|c|}{ Wilcoxon Signed Rank Stats } \\
\hline & & $\mathrm{N}$ & Ortalama Sira & Sira Toplamı & p değeri \\
\hline \multirow{4}{*}{$\begin{array}{l}\text { SUR_SON- } \\
\text { SUR_ÖN }\end{array}$} & $\begin{array}{l}\text { Negatif } \\
\text { Sira }\end{array}$ & 5 & 4,70 & 23,50 & \multirow{4}{*}{0,108} \\
\hline & $\begin{array}{l}\text { Pozitif } \\
\text { Sira }\end{array}$ & 2 & 2,25 & 4,50 & \\
\hline & Ties & 0 & & & \\
\hline & Toplam & 7 & & & \\
\hline \multirow{4}{*}{$\begin{array}{l}\text { BECK_SON- } \\
\text { BECK_ÖN }\end{array}$} & $\begin{array}{l}\text { Negatif } \\
\text { Sira }\end{array}$ & 5 & 3,30 & 16,50 & \multirow{4}{*}{0,207} \\
\hline & $\begin{array}{l}\text { Pozitif } \\
\text { Sira }\end{array}$ & 1 & 4,50 & 4,50 & \\
\hline & Ties & 1 & & & \\
\hline & Toplam & 7 & & & \\
\hline \multirow{4}{*}{$\begin{array}{l}\text { DUR_SON- } \\
\text { DUR_ÖN }\end{array}$} & $\begin{array}{l}\text { Negatif } \\
\text { Sira }\end{array}$ & 6 & 4,17 & 25,00 & \multirow{4}{*}{0,063} \\
\hline & $\begin{array}{l}\text { Pozitif } \\
\text { Sira }\end{array}$ & 1 & 3,00 & 3,00 & \\
\hline & Ties & 0 & & & \\
\hline & Toplam & 7 & & & \\
\hline
\end{tabular}

Sonuçlar incelendiğinde Tablo 1'de açıkça görülmektedir ki Beck umutsuzluk ölçeğinden elde edilen puanların işlem öncesi ve sonrasında anlamlı bir biçimde değişmediği görülmektedir. Durumluk ve sürekli kaygı ölçeklerinden elde edilen puanlar da ayrı ayrı incelendiğinde işlem öncesi ve sonrası için anlamlı bir farklılık bulunamamıştır. Tabloya bakıldığında grup üyelerinin grup çalışması öncesi ve sonrası kaygı ve umutsuzluk düzeylerinde meydana gelen farklılıklar gösterilmiştir. Bu noktada grup üyelerinin kaygı ve umutsuzluk düzeylerine ilişkin bazılarında negatif yönde (kaygı ve umutsuzluk düzeylerinde azalma) bazılarında ise pozitif yönde değişimin olduğu (kaygı ve umutsuzluk düzeylerinde artış) bazılarında ise hiç değişimin yaşanmadığı tespit 
edilmiştir. Tüm test işlemleri için p-değeri> 0.05 olduğu görülmektedir. Yani sıfır hipotezi "İşlem öncesi ve sonrası medyanlar arasında farklıl1k yoktur." reddedilememiştir.

Tablo 2: Üyelerin Ölçeklerden Aldıkları Puanlara Göre Ön-Test ve Son-Test Puanlarına İlişkin İstatistikler Sonuçları

\begin{tabular}{lllllll}
\hline & \multicolumn{2}{l}{ BECK UMUTSUZLUK } & \multicolumn{2}{l}{ DURUMLUK KAYGI } & \multicolumn{2}{l}{ SÜREKLI KAYGI } \\
\cline { 2 - 7 } & ÖN- TEST & SON-TEST & ÖN-TEST & SON-TEST & ÖN-TEST & SON-TEST \\
\hline Ort. & 5,286 & 2,714 & 41,429 & 23,429 & 48,143 & 43,286 \\
ss. & 4,608 & 1,799 & 11,385 & 7,892 & 12,335 & 8,902 \\
s. hata & 1,742 & 0,680 & 4,303 & 2,983 & 4,662 & 3,364 \\
örn. sayisı & 7 & 7 & 7 & 7 & 7 & 7 \\
\hline
\end{tabular}

Ancak; Tablo 2'ye bakıldığında özet istatistikler incelendiğinde Beck umutsuzluk, Durumluk kaygı ve Sürekli kaygı ölçeklerine ait pre-post puanları arasındaki azalışlar dikkat çekmektedir. Sezgisel olarak örnek sayısının az olması ilgili testin anlamsız sonuçlanmasına sebep olmuştur denebilir.

\section{Tartışma}

Sosyal hizmet bölümü stajyer öğrencilerinin iş bulma kaygılarını ve umutsuzluklarını azaltmaya yönelik bilgi ve beceri paylaşımında bulunularak öğrencilerin iş bulma motivasyonunun arttırılması için yapılan grup çalışması planlandığı gibi yedi oturum olarak gerçekleştirilmiştir. Grup süreci genel olarak şu şekilde sürmüştür:

- Her oturum için ısınma oyunları ve drama etkinlikleri yapılmış, katılımcıların oturuma motive olmaları sağlanmıştır.

- Her oturuma, önce 1sınma etkinliğiyle başlanmış sonrasında o oturum için planlanan konu üzerine bilgi paylaşımlarında bulunulmuş, oturum sonunda ise her grup üyesinden o oturumun nasıl geçtiği üzerine değerlendirmeler alınmış ve katılımcılara ev ödevleri verilmiştir. Grup süresince oturumlarda genel akışın dışına çıkılmamış ve oturumlar planlandığı gibi 75 dakika olacak şekilde gerçekleşmiştir.

Sosyal hizmet bölümü stajyer öğrencilerinin iş bulma kaygılarını ve umutsuzluklarını azaltmaya yönelik tasarlanan grup çalışmasının birinci oturumundan önce ve yedinci oturumundan sonra katılımcılara uygulanan Beck Umutsuzluk Ölçeği ve Durumluk- Sürekli Kaygi Ölçeği 'ne ait ön test ve son test puanları incelendiğinde işlem öncesi ve işlem sonrası puanlarında anlamlı bir farklılık bulunamamıştır. Ancak; çalışmanın ikinci bulgusuna bakıldığında grup üyelerinin ölçeklere ait ön test ve son test puanlarına bakıldığında hem sürekli kaygı hem de durumluk kaygı ve umutsuzluk puanlarında dikkate değer bir azalma söz konusu olmuştur. Ayrıca grup çalışmasının sonunda grup üyelerinden alınan "grup çalışmasının kendilerini geliştirdiği, iş bulabilme kaygılarını azalttığı, kendilerini iş bulabilme konusunda cesaretlendirdiği, umutlarını arttırdığı" gibi dönütler çalışmanın bu bulgusunu destekler niteliktedir.

Araştırmanın diğer bir bulgusuna göre grup sürecinin başında mezun olduktan sonra iş bulabileceğini umut etme durumuna katılımcıların \%28,58'i "Evet" derken grup sürecinin sonunda ise bu oran \%100'e çıkmıştır. Yine grup çalışmasıyla birlikte grup üyelerinin \%71,42'si mezun olduktan sonra iş bulabilmeyi ümit ettiği süreyi grup süresinin başında 12-23 ay olarak ifade ederken bu grup çalışmasının sonunda katılımcıların \% 85,72'si 0-11 ay olarak düşüncelerini değiştirmiştir. Yani yapılan grup çalışmasının grup üyelerinin iş bulma motivasyonunu olumlu yönde etkilediği, grup üyelerinin mezun olduktan sonra iş bulabilmeyi umut ettikleri süreyi düşürdüğü söylenebilir. Bununla birlikte yapılan grup çalışması, daha önceden grup çalışması deneyimi olmayan öğrencilere 
gruplarla sosyal hizmet uygulaması kapsamında sosyal hizmet eğitimi açısından canlı bir deneyim sunmuştur. Ancak araştırmaya dair grup çalışmasının sonunda olumlu dönütler alınsa da ölçeklere ait puanlarda bir azalma olsa da ölçeklere ait ön test ve son test puanları arasında istatistiksel olarak anlamlı bir farklılık olmamıştır. Buradan hareketle;

- Grup çalışması programındaki haftalık oturum konularının araştırmanın amacına uygun olup olmadiğ 1 ,

- Grup çalışmasındaki oturum sayısının ve grup çalışmasında yer alan örnek sayısının yeterliliği,

grup çalışmasının amacına ulaşması açısından tartışılması gereken sorulardır. Bu noktada ön test ve son test arasında anlamlı bir farklılığın çıkmaması ve yapılan grup çalışmasındaki olumlu dönütlerin, çalışma sonunda grup üyelerindeki kaygı ve umutsuzluk puanlarındaki azalmanın tesadüfi olup olmadığının araştııılması açısından çalışmanın başka bir örneklem grubuyla, farklı örnek sayılarıyla yapılması önerilmektedir.

Sosyal hizmet bölümü başta olmak üzere üniversitelerin diğer bölümlerinde okuyan son sınıf öğrencilerinin ya da stajyer öğrencilerin kaygı ve umutsuzlukları, gelecekte iş bulma kaygıları üzerine yapılan araştırmalar incelendiğinde ilgili literatürde araştırmaların çoğunun korelasyonel ve tarama araştırmaları olduğu, grup çalışması yöntemiyle herhangi bir deneysel araştırma yapılmadığı görülmektedir. Tekin Tayfun ve Korkmaz (2016)'1n “Üniversite Öğrencilerinde İşsizlik Kaygisı: Süleyman Demirel Üniversitesi Öğrencileri Üzerinde Bir Araştırma" isimli çalışmalarında üniversite son sınıf öğrencilerinin işsizlik kaygısı yaşadığı tespit edilmiştir. Araştırmada öğrencilerin iş bulma kaygısı yaşamalarında kişisel karamsarlık ve özgüven eksikliği, niteliksel olarak bilgi ve beceri eksikliği gibi faktörlerinde etkili olduğu sonuçlarına ulaşılmıştır. Bu açıdan bu araştırmada tespit edilen iş bulma kaygısı üzerindeki faktörler ile grup çalışmasının programının amaçları paralellik göstermektedir. Şanlı K. ve Saraç (2017) da üniversite öğrencileriyle yaptıkları çalışmada son sınıf öğrencilerinin genel olarak umutsuzluk düzeylerinin hafif olduğunu ancak; çalışmada ileri düzeyde umutsuzluk yaşayan öğrencilerinde bulunduğunu saptamışlardır. Üstün ve diğerleri (2014) ile Demir ve Taşkıran (2018) tarafından yapılan araştırma sonuçlarında da öğrencilerin çoğunun iş bulma ümitlerinin ve iş bulmaya ilişkin umutsuzluk düzeylerinin bazı değişkenlere göre değişiklik gösterdiği belirlenmiştir.

Taşğın, Bozgeyikli ve Boğazlıyan (2017) yaptıkları çalışmada üniversite öğrencilerinin psikolojik dayanıklılıklarının arttıkça işsizlik kaygı düzeylerinin düştüğünü saptamışlardır. Çalışma da üniversite öğrencilerinin iş bulma kaygısını azaltmaya yönelik öğrencilerin psikolojik dayanıklılıklarını arttırma ve geliştirme çalışmalarının yapılması gerektiği belirtilmiş, bu sayede öğrencilerin iş arama sürecinde sağliklı karar alma ve kişisel gelişimlerini devam ettirebilme becerileri kazanabilecekleri ileri sürülmüştür. Öz ve Topuz (2014) "Türkiye'de Sosyal Hizmet Uzmanlarının İstihdam Durumu" isimli araştırmalarında sosyal hizmet bölümlerinin plansız ve hızlı bir şekilde büyüdügünü, sosyal hizmet bölümlerinin hem örgün hem açıköğretim bölümü olarak açılmaya başladığını bu yüzden açılan bölümlerin vereceği mezunlara göre yeni istihdam alanlarının yaratılması gerektiğini aksi takdirde bunun sosyal hizmet uzmanları için işsizlik sorunu olarak ortaya çıkacağını belirtmişlerdir. Yine Sevim ve Altun (2017)'un sosyal hizmet bölümü öğrencileriyle yaptığı çalışmada öğrencilerin mesleki gelecek kaygılarının yüksek olduğu tespit edilmiştir. Choi ve Haeyoung (2013) "Üniversite Öğrencilerinin İstihdam Sorunları" isimli araştırmalarında üniversite öğrencilerinin işsizlik stresi ile fiziksel semptomlar, ruh sağlığı ve benlik saygısı gibi faktörleri etkileyen korelasyonu incelemişlerdir. Araştırma sonucunda dördüncü sınıfta öğrencilerin iş bulma stresinin ve depresyon düzeyinin daha yüksek çıktığı bulunmuş bu nedenle öğrencilere yönelik alt sınıflarda işe hazırlama programı planlanması, istihdam bilgilerinin sağlanmasıyla birlikte benlik 
saygılarını arttırmaya ve depresyon düzeylerini kontrol etmeye yönelik stratejilerin geliştirilmesi gerektiği önerilmiştir.

Diğer taraftan sosyal hizmet disiplinin de yapılan grup çalışmaları sayısının da az olduğu ve sosyal hizmet mesleğine ilişkin kariyer, istihdam, iş bulma gibi konularda herhangi bir grup çalışması yönteminin kullanıldığı bir araştırma da görülmemektedir. Yapılan literatür taramaları sonunda Türkiye'de gruplarla sosyal hizmet müdahalesi kullanılarak yapılan çalışmaların son yıllarda yaygınlaştı̆̆ 1 görülmektedir ve bu çalışmalardan bazıları; Sosyal Grup Çalışması Uygulamasının Psikolojik Gereksinimlere Etkisi (Duyan ve Gökçearslan, 2004), Ergenler İçin Kentin Riskleri: Grupla Sosyal Hizmet Müdahalesi Örneği (Çoban ve Bulut, 2016), Kronik Hastalıklarla Baş Etmede Çoklu Aile Grubu Terapisi Uygulamaları (Pak, 2019), Grup Çalışmasının Kadın Hükümlülerin Sosyal Sorun Çözme Becerilerine Etkisi (Akgün, 2018), Sosyal Hizmet Uygulaması Olarak Özel Gereksinime Sahip Çocuklarla Değerler Eğitimi Grup Çalışması (Tekindal ve Negiz, 2018), Değerler Eğitimi Aracıllğıyla Sosyal Uyum: Suriyeli ve Türkiyeli Lise Öğrencileri Özelinde Bir Uygulama (Negiz ve ark., 2019) isimli yapılan çalışmalardır. Benzer şekilde Tekindal'da (2019) göçmen kadınlarla nasıl grup çalışmasının yapılandırılabileceğini tasarlamak için "A Feminist Group Work Design With Women Refugees in Turkey" çalışmasını kaleme almıştır.

\section{Sonuç}

Sosyal Hizmet bölümü stajyer öğrencilerinin iş bulma kaygısı ve umutsuzluk düzeylerini azaltmaya, iş bulmaya yönelik motivasyonlarını ise arttırmaya yönelik yapılan bu grup çalışması programının etkililiğinin sınandığı bu araştırmada ölçeklere ait ön test ve son test puanları arasında anlamlı bir farklılık çıkmasa da grup üyelerinin kaygı ve umutsuzluk düzeylerinin azaldığı, katılımcıların grup çalışması sonunda olumlu dönütler verdiği görülmüştür. Bununla birlikte ilgili alanyazın incelemesi sonucunda da sosyal hizmet disipliniyle ilgili yapılan grup çalışmalarının yeterli düzeyde olmadığ 1 görülmüştür. Sosyal hizmet bölümü stajyer öğrencileriyle yapılan bu grup çalışması da hem gruplarla sosyal hizmet uygulaması olması hem de üniversite öğrencilerine yönelik yapılan bir meslek danışmanlığı uygulaması olması yönüyle alana katkı sağlayacak ve öğrencilerin iş bulma kaygısı ve umutsuzluk düzeyini azaltma ve gelecek motivasyonlarının sağlanması açısından faydalı olacaktır. Bu doğrultuda geliştirilecek grup çalışmalarının yapılmasının mesleğe başlayacak öğrencilere mesleki açıdan kişisel özgüvenleri sağlamada, motivasyonlarını ve iş bulma ümitlerini arttırmada ve mesleki donanımlarını güçlendirme noktasında destek olacağı düşünülmektedir.

Araştırmada ulaşılan bulgular neticesinde üniversite öğrencilerinin iş bulma kaygısı ve umutsuzluk düzeylerini azaltmaya yönelik ileride yapılacak çalışmalara şu öneriler getirilmiştir:

- $\mathrm{Bu}$ araştırmada grup çalışması ile etkililiği sınanan mesleki grup rehberliği programı sosyal hizmet bölümü stajyer öğrencileri için planlanmış ve uygulanmıştır. Araştırmadan elde edilen sonuçlar neticesinde grup çalışması programının başka örnek gruplarıyla yapılması önerilmektedir. Yapılan çalışma kontrol grupsuz ön test ve son- testin olduğu deneysel bir çalışmadır. İleride yapılacak benzer araştırmaların kontrol grubuyla birlikte yapılması önerilmektedir.

- Sosyal hizmet disiplininde önemli bir sosyal hizmet müdahalesi olarak kullanilan gruplarla sosyal hizmet yöntemine yönelik akademik çalışmaların arttırılması, bölüm öğrencilerinin mesleki kariyerleri, istihdam durumları, mezun olduktan sonra iş bulabilmelerine ilişkin kaygı ve umutsuzluk gibi ruhsal durumlarını saptamayı ve iyileştirmeyi hedefleyen araştırmaların yapılarak alandaki eksikliğin doldurulması önerilmektedir. 


\section{Kaynakça}

Akgün, R. (2018). Grup Çalışmasının Kadın Hükümlülerin Sosyal Sorun Çözme Becerilerine Etkisi. Journal SMART, 4(9), 129-137.

Alptekin, K., Topuz, S., \& Zengin, O. (2014). Türkiye'de Sosyal Hizmet Eğitiminde Mevcut Durum: Tespitler, Analizler, Öneriler. Uluslarası Katılımlı Sosyal Hizmet Sempozyumu (s. 353-366). Kocaeli Üniversitesi.

Alptekin, K., Topuz, S., \& Zengin, O. (2017). Türkiyede Sosyal Hzimet Eğitiminde Neler Oluyor? Toplum ve Sosyal Hizmet, 28(2), 50-69.

Başer, D. (2018). Sosyal Hizmet Öğrencilerinin KPSS'ye Hazırlık Süreçlerinin Sosyal Hizmet Eğitmine Yansımaları: Nitel Bir Araştırma. Sosyal Politika Çalışmaları Dergisi, 18(41), 359-383.

Beck, A., Weissman, A., Lester, D., \& Trexler, L. (1974). The Measurement of Pessimism. The Hopelessness Scale. Journal of Consulting and Clinical Psychology, 42, 861-865.

Büyüköztürk, Ş., Kılıç Çakmak, E., Akgün, Ö. E., Karadeniz, Ş., \& Demirel, F. (2008). Bilimsel Araştırma Yöntemleri. Pegem Akademi.

Choi, S.-H., \& Haeyoung, L. (2013). 대학생의 취업스트레스에 영향을 미치는 요인 -신체증상, 우울, 불안, 자아존중감을 중심으로. 한국콘텐츠학회논문지 제, 13(12), 808-816. doi:http://dx.doi.org/10.5392/JKCA.2013.13.12.808

Çoban, A. İ., \& Bulut, I. (2016). Ergenler İçin Kentin Riskleri: Gruplarla Sosyal Hizmet Müdahalesi Örneği. Journal of Human Sciences, 13(3), 4312-4324.

Danış, M. Z. (2007). Sosyal Hizmet Mesleği ve Disiplininde Sosyal Politikanın Yeri ve Önemi. Toplum ve Sosyal Hizmet, 18(2), 51-64.

Demir, Ö., \& Taşkıran, G. (2018). İ̈BF Mezun Adaylarının İş Bulma Ümitlerini Etkileyen Faktörler Üzerine Nicel Bir Araştırma. Çalışma İlişkileri Dergisi, 9(1), 42-57.

Dilbaz, N., \& Seber, G. (1993). Umutsuzluk Kavramı: Depresyon ve İntiharda Önemi. Kriz Dergisi, $1(3), 134-138$.

Duman, S., Taş̆̆ın, Ö., \& Özdağ, S. (2009). Beden Eğitimi Ve Spor Yüksekokulu Spor Yöneticiliği Bölümünde Okuyan Öğrencilerin Umutsuzluk Düzeylerinin İncelenmesi. Selçuk Üniversitesi Beden Eğitimi ve Spor Bilim Dergisi, , 11(3), 27-32.

Durak, A. (1994). Beck Umutsuzluk Ölçeğinin Geçerlik ve Güvenirlik Çalışması. Türk Psikoloji Dergisi, 9(31), 1-11.

Dursun, S., \& Aytaç, S. (2009). Uludă̆ Üniversitesi İktisadi ve İdari Bilimler Fakültesi Dergisi, 28(1), 71-84.

Duyan, V., \& Gökçearslan, E. (2004). Sosyal Grup Çalışmasının Uygulamasının Psikolojik Gereksiinmlere Etkisi. Toplum ve Sosyal Hizmet, 15(1), 61-74.

Erdoğan, E. G., \& Akın, B. (2016). Hemşirelik Son Sınıf Öğrencilerinin İş Bulma Endişeleri ve Umutsuzluk Düzeyleri. Ege Üniversitesi Hemşirelik Fakültesi Dergisi, 32(1), 72-89.

Gökçearslan Çiftçi, E., \& Gönen, E. (2011). Sosyal Hizmet Uygulamalarında Etik Karar Verme Süreci. Toplum ve Sosyal Hizmet, 2(22), 149-160. 
Işıkhan, V., Erbay, E., Akçay, S., \& Ege, A. (2016). Sosyal Hizmet Bölümü Öğrencilerinin Mezuniyet Sonrası Gelecek Planları: Ankara, Başkent ve Hacettepe Üniversitesi Örneği. Toplum ve Sosyal Hizmet, 27(1), 1-18.

Kıcır, B. (2010). Üniversite Son Sınıf Öğrencilerinde İşsizlik Kaygısı:Psikolojik Etmenler Açısından Bir İnceleme. Yüksek Lisans Tezi. Ankara Üniversitesi Sosyal Bilimler Enstitüsü.

Kongar, E. (1978). Insanı Yönlendirme ve Sosyal Hizmetler (Sosyal Çalışmaya Giriş) (2 b.). Hacettepe Üniversitesi Yayınları.

Küçük, U., Usta, G., \& Torpuş, K. (2019). Sağlık Hizmetleri Meslek Yüksekokulu Son Sınıf Öğrencilerinin İş Bulma Endişeleri ve Umutsuzluk Düzeyleri. ACU Sağglı Bilimleri Dergisi, 10(3), 367-372.

Lord, S. (2008). Therapeutic Work with Trauma,Revictimization, and Perpetration: Bearing Witness, Offering Hope, Embracing Despair. Psychoanalytic Social Work, 15(2), 110-132.

Negiz, E., Demircioğlu, E. E., \& Tekindal, M. (2019). Değeler Eğitimi Aracılığıyla Sosyal Uyum: Suriyeli ve Türkiyeli Lise Öğrencileri Özelinde Bir Uygulama. Uşak Üniversitesi Sosyal Bilimler Dergisi, 72-89.

Öner, N., \& Le Compte, A. (1983). Durumluk- Sürekli Kaygl Envanteri El Kitabı. Boğaziçi Üniversitesi Yayınları.

Pak, M. D. (2019). Kronik Hastalarla Baş Etmede Çoklu Aile Grubu Terapisi Uygulamaları. Toplum ve Sosyal Hizmet, 30(3), 1120-1141.

Seber, G. (1991). Beck Umutsuzluk Ölçeğinin Geçerlik ve Güvenirliği Üzerine Bir Çalışma. Doçentlik Tezi. Anadolu Üniversitesi Sağl1k Bilimleri Enstitüsü.

Seber, G., Dilbaz, N., Kaptanoğlu, C., \& Tekin , D. (1993). Umutsuzluk Ölçeği: Geçerlilik ve Güvenirliliği. Kriz Dergisi, 1(3), 139-142.

Sevim, K., \& Altun, F. (2017). Sosyal Hizmet Bölümü Öğrencilerinin Geleceğe Yönelik Mesleki ve Akademik Beklentileri. AÇÜ Uluslararası Sosyal Bilimler Dergisi, 3(2), 51-65.

Sheafor, B., \& Horejsi, C. (2016). Sosyal Hizmet Uygulaması Temel Teknikler ve ilkeler (3 b.). (D. B. Çiftçi, Dü., \& O. Uraz, Çev.) Nika Yyaınevi.

Spielberger, C., Jacobs, G., Russell, S., \& Crane, R. (1983). Assessment of Anger: The State-Trait Anger Scale. In J. N. Butcher, \& C. D. Spielberger (Eds.). Advances in Personality Assessment, 2, 159-187.

Şanlı Kula, K., \& Saraç, T. (2017). Üniversite Öğrencilerinin Umutsuzluk Düzeylerinin İncelenmesi. Eskişehir Osmangazi Üniversitesi Sosyal Bilimler Dergisi, 18(1), 1-16.

Taşğın, Ö., Bozgeyikli, H., \& Boğazlıyan, E. E. (2017). Üniversiteli Gençlerin İşşizlik Kaygıları ile Psikolojik Dayanıklılıkları Arasındaki İlişki. Emek ve Toplum, 6(6), 552-567.

Taşpınar Göveç, N., \& Başgül, Ş. (2017). Psikodrama ve Bilişsel Davranışçı Terapi Yöntemi ile Grup Çalışmasının Sınav Kaygısı Üzerindeki Etkileri. Bilişssel Davranışçı Psikoterapi ve Araştırmalar Dergisi, 5(1), 1-5.

Tekin Tayfun, A., \& Korkmaz, A. (2016). Üniversite Öğrencilerinde İşşizlik Kaygısı: Süleyman Demirel Üniversitesi Öğrencileri Üzerinde Bir Araştırma. Mehmet Akif Ersoy Üniversitesi Sosyal Bilimler Enstitüsü Dergisi, 8(17), 534-558.

Tekindal, M. (2019). Türkiye'de Kadın Mültecilerle Feminist Grup Çalışması Dizaynı. Sosyal Politika Çalışmaları Dergisi(43), 11-32. 
Tekindal, M., \& Negiz, E. (2018). Sosyal Hizmet Uygulaması Olarak Özel Gereksinime Sahip Çocuklarla Değerler Eğitimi Grup Çalışması. Journal of Awareness, 3, 761-776.

Topuz, S., \& Öz, M. (2014). Türkiye'de Sosyal Hizmet Uzmanlarının İstihdam Durumu. Toplum ve Sosyal Hizmet, 25(1).

Türkiye İstatistik Kurumu. (2019). İstihdam Oranlarl. Türkiye İstatistik Kurumu. http://www.tuik.gov.tr/UstMenu.do?metod=istgosterge adresinden alındı

Türkiye İstatistik Kurumu. (2019). İşsizlik Oranı. Ankara: Türkiye İstatistik Kurumu. http://www.tuik.gov.tr/UstMenu.do?metod=istgosterge adresinden alınd

Üstün, G., Dedekoç, Ş., Kavalalı, T., Öztürk, F., Sapcı, Y., \& Can, S. (2014). Üniversite Son Sinıf Öğrencilerinin İş Bulmaya İlişkin Umutsuzluk Düzeylerinin İncelenmesi. Amasya Üniversitesi Eğitim Fakültesi Dergisi, 3(2), 200-221.

Yapısal Eşitlik Modeli İle Öğrencilerin İş Bulma Kaygılarına Yönelik Ölçek Geliştirme: Cumhuriyet Üniversitesi İ̈BF'de Bir Uygulama. (2016). Yüksek Lisans Tezi. Cumhuriyet Üniversitesi Sosyal Bilimler Enstitüsü.

Yükseköğretim Bilgi Yönetim Sistemi. (2020, 05 25). Yükseköğretim İstatistikleri. https://istatistik.yok.gov.tr/. adresinden alınd1

Zastrow, C. (2014). Sosyal Hizmete Giriş. (D. B. Çiftçi, Dü., E. Bahşi, \& Ç. Karaca, Çev.) Nika Yayınevi. 